\title{
THE WATER RESOURCES IN THE TREBES-NEGEL HYDROGRAPHIC BASIN (ROMANIA)
}

DOI: http://dx.doi.org/10.18509/GBP.2018.04

UDC: 556.512(498)

\author{
Larisa Paveluc ${ }^{1,2}$ \\ Gianina Cojoc ${ }^{2}$ \\ Alina Tirnovan ${ }^{2}$ \\ ${ }^{1}$ Alexandru Ioan Cuza University of Iasi, Faculty of Geography and Geology, Department of \\ Geography, Bd. Carol I 20A, 700505, Iasi, Romania \\ ${ }^{2}$ Siret Water Basin Administration, Bacau, 1 Cuza Voda Str., 600274, Bacau, Romania
}

\begin{abstract}
This study aims to analyze the surface waters of the Trebes River. The Trebes-Negel River Basin is also known as the representative basin and it is the right tributary of the Bistrita River. The monitoring of this river reflects in a database necessary for the analysis of the long-term tendency of the hydrological regime, both in natural conditions and influenced by anthropogenic activities. The contact area between the Eastern SubCarpathians, in their middle part, and the Central Moldavian Plateau present a series of morphological peculiarities determined by a corrugated and varied structure, by an alternation of tough hard rocks and the action of the flowing water. These morphohydrographic peculiarities corroborated with climatic conditions dependent on the latitude, orientation and altitude of the major relief forms are determinant for genesis and flow regime. The first advantage in studying small river basins is that the results can be extrapolated for larger basins. Also, the magnitude of the analyzed data is smaller. The results of this study can certainly provide important information and can contribute to the implementation of effective measures in order to protect and prevent floods. The results of this study play an important role in the elaboration of hydrological prognosis of immediate or long-term utility because it is necessary to know in detail the variability in time and space of some hydrological parameters. The current period is characterized by an economic distinguished soar that requests for increasingly more water as a component of technological processes or as an indispensable part of sanitation for large human agglomerations.
\end{abstract}

Key words: management, Moldova, representative basin, river basin, surface water

\section{INTRODUCTION}

Understanding in detail the hydro-meteorological processes that lead to the formation of runoff and its treatment has been proved to be required for the settlement of practical problems. The zonality character (latititude) and the natural setting (altitude) manifested by the hydro-meteorological phenomena, plus a series of local peculiarities imprinted by the detailed physical-geographical characteristics, require some intensive observations and measurements in determining the relationships between precipitation and drainage. The study is focused, in particular, on a small, representative river basin - Trebes-Negel. The Trebes-Negel River Basin, considered as representative by the Romanian Waters, is 
an important objective in hydrological terms, for the Carpathian area, being monitored since 1980 [1].

The water resource is intensely studied at an international level [2-8] and national [9-11]. The problem is the quality of the surface water [12-17], the minimum and maximum drainage at different times of the year [18-31] and at the same time on the water requirement in different climates [32-34]. The present study aims to analyze the water resources from the small water basins. Unfortunately most communities in Romania exploit only surface waters and rarely the ground waters. For this reason there is an overexploitation of the resources from rivers and very often the legislation regarding the ecological flow is violated.

\section{STUDY AREA}

The Trebes River (also known as Trebis), with the most important tributary - Negel belongs to the lower Basin of Bistrita River, the confluence being near Bacau City (downstream Bacau Dam) at the level $141.50 \mathrm{~m}$. The Trebes River Basin has $140 \mathrm{~km}^{2}$ areas which extend to NE direction. On the right side, the most important tributaries that can be identified are the small rivers Fantana Pustnicului and Limpedea, and on the left Slatina, Carligati and Negel. It is situated between the parallels $46^{\circ} 30^{\prime}$ and $46^{\circ} 40^{\prime}$ northern latitude and the meridians $26^{\circ} 40^{\prime}$ and $26^{\circ} 52^{\prime}$ eastern longitude (Fig. 1).

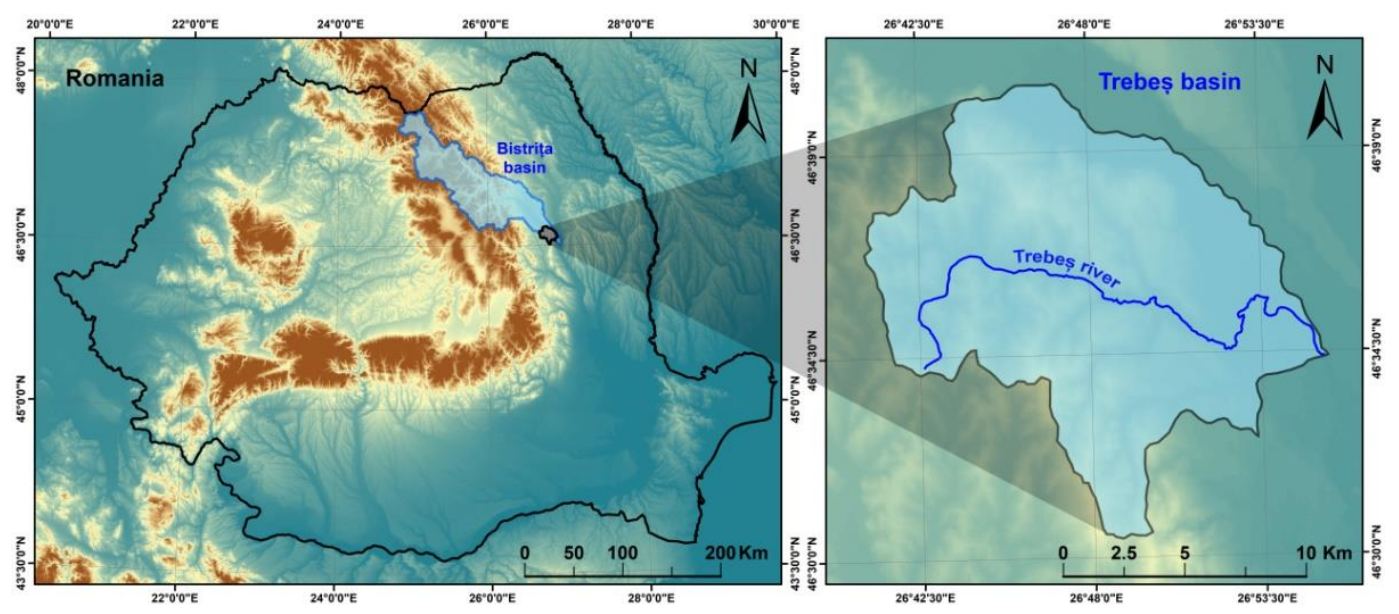

Figure 1. The geographical localization of Trebes River Basin

There are three most important hydrometrical stations in Trebes River Basin: Podis and Margineni on the Trebes River and Magura on the Negel River. The annual flowing volume on the Trebes River is $11870000 \mathrm{~m}^{3}$ (Table 1).

Table 1. The hydrometrical stations in Trebes River Basin

\begin{tabular}{ccccc}
\hline \multirow{2}{*}{ River } & Hydrometrical station & $\begin{array}{c}\text { Area } \\
\left(\mathrm{km}^{2}\right)\end{array}$ & $\begin{array}{c}\text { Multiannual flow } \\
\left(\mathrm{m}^{3} / \mathrm{s}\right)\end{array}$ & $\begin{array}{c}\text { Runoff volume } \\
\left(\mathrm{m}^{3} / \text { year }\right)\end{array}$ \\
\hline Trebes & Podis & 23.9 & 0.099 & 3124000 \\
Negel & Magura & 12.9 & 0.063 & 1988000 \\
Trebes & Margineni & 125 & 0.376 & 11870000 \\
\hline
\end{tabular}




\section{METHODOLOGY}

The hydrological data are obtained from Siret Water Basin Administration (Bacau) and it covers a period of 48 years. The program of observations and measurements conducted in the representative basin leads to a background data useful both for practical purposes and for basic research.

The hydrometrical stations existent on Trebes River are Podis hydrometric station and Margineni hydrometric station, and on Negel River there is only one hydrometric station - Magura hydrometric station. The hydrological basins corresponding to these sections are poorly afforested and the predominant vegetation consists of grasslands, meadows and agricultural crops. The relief is heavily fragmented and the sediment load is rich. Within the hydrological basin are being monitored the following hydrometrical stations: Tocila River - Luncani Section. The Tocila subbasin has a degree of afforestation of 40 $-50 \%$ (especially in the superior sector) and large sections of drainage. The relief is high and heavily fragmented. The program implies the monitoring of levels, flows and precipitation;

Trebes River - Luncani Section. This section represents the closure for the first third of the Trebes River basin, including the Tocila River;

Slatina River - Chetrosu Section. The Slatina subbasin has a high degree of afforestation $(80 \%)$;

Trebeş River - Chetrosu Section. This section closes the sections upstream;

Valea Budului River - Valea Budului Section. This is a subbasin afforested 100\%. The hydrometrical station has a program of observation and measurements for levels, flows, sediment loads, temperatures, and precipitations.

Trebes River - Valea Budului Section. This section closes the sections upstream;

Trebes River - Margineni Section. The hydrometrical station is placed at the closure of Trebes River Basin, downstream the confluence to Negel River;

Negel River - Magura Section. This section monitors a surface of $18 \mathrm{~km}^{2}$, being placed on the highest and the most afforested sector of Pietricica Peak.

The program implies the monitoring of levels, flows, sediment load, temperatures (water and air), and precipitations.

\section{RESULTS AND DISCUSSIONS}

In the Trebes River Basin placed in the Eastern Carpathians area we can identify the Subcarpathian ripple formations (successions of marl, clay, sandstone and conglomerates) from Badenian and Burdigalian, and platform deposits (marl, clay, sand) from the Sarmatian age. The Quaternary deposits (pebbles, gravels, loessoid tiles, etc) are extended in valleys and terraces. [35]

The relief is extremely varied although the surface of the basin is reduced. This is the consequence of the interdependence between the structure and the geological composition and the action of the external agents, especially the flowing waters. The river valleys are narrow and deep, only Pietricica Peak has larger slope valleys [36].

The climate is temperate with continental influence. The average annual temperature is $9.2^{\circ} \mathrm{C}$. The temperature of the January month is $-4^{\circ} \mathrm{C}$, and that of the July month is $20^{\circ} \mathrm{C}$. Significant from the thermal point of view are the thermal inversions, especially in winter. The dominant direction of the winds is V-E and NV-SE [37].

The formation of water runoff and sediment load is influenced by physical-geographical factors. The Podzolic soils of forest with some degree of iluvial clays and leaching of 
salts are prevalent. In the lower areas the soils have gleyzation and marshy tendencies and on meadows the alluvial intrazone soils develops. Generally, soils are lighter but the large percentages of clay favors water immiscibility and facilitate waterproofing. For this reason the drainage coefficient is higher. The large drainage slopes and the torrential character of the rainfall allow the development of processes of erosion and soil degradation. The dominant vegetation is hardwood forest (oak, beech, hornbeam). Locally, on higher sectors, can be found mixed enclaves of beech and spruce. The forest covers about $60 \%$ of the surface of the basin. The largest forest woodlands are found in the subbasins Slatina, Valea Budului, Negel (the upstream sector), Seaca and Tocila. The hydrographical network is relatively dense $\left(0.94 \mathrm{~km} / \mathrm{km}^{2}\right)$ and numerous due to the relief conditions, climate and vegetation. The Trebes River Basin has a surface of 107 $\mathrm{km}^{2}$ and the Negel River Basin $34 \mathrm{~km}^{2}$. From 1970 the Negel River, downstream Magura, was conducted through an artificial canal in Trebes and became a tributary of it on the right side. The other rivers that constitute the hydrographic network of the Trebes River Basin are: Slatina $\left(\mathrm{F}=11 \mathrm{~km}^{2}\right)$; Carligati $\left(\mathrm{F}=14 \mathrm{~km}^{2}\right)$; Valea Budului on the right side and Dubas, Tocila, Valea Seaca and Rosca on the left side.

Usually, rivers with a surface of more than $8-10 \mathrm{~km}^{2}$ do not dry out. The drainage regime is characterized by low flows in winter and autumn and higher in spring and summer. The frost phenomena have a different annual frequency and duration (usually between Decade III-December and Decade I-March) (Table 2). The multiannual average flow of Trebes River at Margineni hydrometrical station is $0.376 \mathrm{~m}^{3} / \mathrm{s}$.

Table 2. Multiannual monthly average flows $1970-2017$

\begin{tabular}{|c|c|c|c|c|c|c|c|c|c|c|c|c|c|c|}
\hline River & $\begin{array}{c}\text { Hydrometrical } \\
\text { station }\end{array}$ & I & II & III & IV & $\mathrm{V}$ & VI & VII & VIII & IX & $\mathrm{X}$ & XI & XII & Average \\
\hline Trebes & Podis & 0.045 & 0.082 & 0.200 & 0.230 & 0.147 & 0.183 & 0.128 & 0.057 & 0.026 & 0.021 & 0.025 & 0.046 & 0.099 \\
\hline Trebes & Margineni & 0.256 & 0.299 & 0.930 & 0.779 & 0.550 & 0.657 & 0.920 & 0.431 & 0.173 & 0.148 & 0.173 & 0.212 & 0.376 \\
\hline Negel & Magura & 0.019 & 0.049 & 0.063 & 0.110 & 0.131 & 0.102 & 0.190 & 0.031 & 0.023 & 0.014 & 0.015 & 0.015 & 0.063 \\
\hline
\end{tabular}

The Trebes River is the area of the Bacau County, which is one of the largest counties of Romania. The River runs through Margineni commune representing $1.24 \%$ of the population of the County of Bacau and $2.29 \%$ of the population of the rural sector. The Margineni commune consists of 8 villages and is located in the immediate vicinity of the city. The population of the commune is approximately 8940 persons, 4514 people male and female 4426 (Table 3, 4).

Table 3. Population structure by age and sex

\begin{tabular}{cccc}
\hline Age & Total & Masculine & Feminine \\
\hline $0-4$ years & 428 & 255 & 173 \\
$5-9$ years & 461 & 229 & 232 \\
$10-14$ years & 485 & 258 & 227 \\
$15-19$ years & 527 & 228 & 299 \\
$20-24$ years & 609 & 309 & 300 \\
$25-29$ years & 625 & 317 & 308 \\
$30-34$ years & 625 & 344 & 309 \\
$35-39$ years & 671 & 348 & 323 \\
$40-44$ years & 641 & 337 & 304 \\
$45-49$ years & 632 & 332 & 300 \\
$50-54$ years & 633 & 317 & 316 \\
$55-59$ years & 629 & 314 & 315 \\
$60-64$ years & 605 & 306 & 299
\end{tabular}




\begin{tabular}{cccc}
$65-69$ years & 587 & 238 & 349 \\
$70-74$ years & 442 & 232 & 210 \\
75 years and more & 312 & 150 & 162 \\
TOTAL & 8940 & 4514 & 4426 \\
\hline
\end{tabular}

Table 4. Population structure by localities and number of households

\begin{tabular}{ccc}
\hline Locality & No. households year 2017 & No. average persons/household \\
\hline Margineni & 1258 & 3.34 \\
Barati & 579 & 3.79 \\
Luncani & 405 & 2.96 \\
Padureni & 159 & 3.14 \\
Podis & 274 & 2.37 \\
Poiana & 78 & 3.84 \\
Trebes & 296 & 3.71 \\
Valea Budului & 176 & 2.84 \\
Total & 3225 & 3.30 \\
\hline
\end{tabular}

As shown the population living within the basin is extremely large (8940 inhabitants) and the multiannual average flow of the river is very low $\left(0.376 \mathrm{~m}^{3} / \mathrm{s}\right)$. For this reason, the volume of water per each inhabitant on an annual basis is very low. Thus, the population is forced to obtain water supply from the groundwater (fountains) or from the river areas nearby.

\section{CONCLUSIONS}

For the elaboration of hydrological forecasts of immediate or long-lasting utility it is necessary to have the time and space variability of hydrological parameters. The human factor is essential in directing hydrological phenomena at the local level. The high density of population within the Trebes River Basin leads different human risks: lack of water (hydrological droughts) or excess (frequent flash floods). That being said, in a relatively small area of $141 \mathrm{~km}^{2}$, it is most probably possible to obtain ideal models relating to water resources and their rational management. The immediate function of the representative Trebes River Basin as a warning basin for the immediate urban agglomeration of Bacau City cannot be neglected.

\section{REFERENCES}

[1] Cojoc G., Romanescu G. \& Tirnovan A. Exceptional floods on a developed river. Case study for the Bistrita River from the Eastern Carpathians (Romania). Natural Hazards, vol. 77, no. 3, pp. 1421-1451, 2015.

[2] Sánchez-Rodríguez A.R., Chadwick D.R., Tatton G.S., Hill P.W. \& Jones D.L. Comparative effects of prolonged freshwater and saline flooding on nitrogen cycling in an agricultural soil, Applied Soil Ecology, 2018.

Doi:https://doi.org/10.1016/j.apsoil.2017.11.022

[3] Su X.\& Nilsson C., Pilotto F., Liu S., Shi S. \& Zeng B. Soil erosion and deposition in the new shorelines of the Three Gorges Reservoir. Science of the Total Environment, vol. 599-600, pp. 1485-1492, 2017.

[4] Testa B., Aldighieri B., D’Alberto L., Lucianetti G. \& Mazza R. Hydrogeology and Hydromorphology: a Proposal for a Dual-Key Approach to Assess the Geo-Hydrological 
Heritage Site of the San Lucano Valley (Belluno Dolomites, Italy). Geoheritage, Italy, pp. 1-20, 2018. https://doi.org/10.1007/s12371-018-0279-y

[5] Tošić R., Lovrić N., Dragićević S. \& Manojlović S. Assessment of torrential flood susceptibility using GIS matrix method: case study - VRBAS river basin (B\&H), Carpathian Journal of Earth and Environmental Sciences, vol. 13, no. 2, pp. 369-382, 2018.

[6] Vasileski D. \& Radevski I. Analysis of high waters on the Kriva Reka river, Acta Geographica Slovenica, vol. 54, no. 2, pp. 363-377, 2015.

[7] Yang H.C., Wang C.Y. \& Yang J.X. Applying image recording and identification for measuring water stages to present flood hazards, Natural Hazards, vol. 74, no. 2, pp. 737-754, 2014.

[8] Zeleňáková M. \& Fijko R.\& Diaconu D.V. \& Remeňáková I. Environmental Impact of Small Hydro Power Plant-A Case Study, Environments, vol. 5, no. 1, pp. 12, 2018.

[9] Serban G., Rus I., Vele D., Bretcan P., Alexe M. \& Petrea D. Flood-prone area delimitation using UAV technology, in the areas hard-to-reach for classic aircrofts: case study in teh northeast of Apuseni Mountains, Transylvania. Natural Hazards, vol. 82, no. 3, pp. 1817-1832, 2016.

[10] Tokar A., Negoitescu A., Hamat C. \& Rosu S. The Chemical and Ecological State Evaluation of a Storage Lake. Rev.Chim.(Bucharest), vol. 67, no. 9, pp. 1860-1863, 2016.

[11] Ungureanu G., Boghita E., Ignat G., Costuleanu C.L., Sandu A.V., Bejinariu C. \& Vintu C.R. Effect of Climate Change on Pedological Modifications and Soil Aridity Process in Vineyards. Rev.Chim.(Bucharest), vol. 68, no. 11, pp. 2662-2671, 2017.

[12] Banaduc D., Rey S., Trichkova T., Lenhardt M. \& Curtean-Banaduc A. The Lower Danube River-Danube Delta-North West Black Sea: A pivotal area of major interest for the past, present and future of its fish fauna - A short review. Science of the Total Environment, vol. 545-546, pp. 137-151, 2016.

[13] Enea A., Hapciuc O.E., Iosub M., Minea I. \& Romanescu G. Water quality assessment in three mountainous watersheds from eastern Romania (Suceava, Ozana and Tazlau rivers). Environmental Engineering and Management Journal, vol. 16, no. 3, pp. 605-614, 2017.

[14] Patroescu V., Jinescu C., Cosma C., Cristea I., Badescu V. \& Stefan C.S. Influence of Ammonium Ions on the Treatment Process Selection of Groundwater Supplies Intended to Human Consumption. Rev. Chim. (Bucharest), vol. 66, no. 4, pp. 537-541, 2015.

[15] Romanescu G., Cretu M.A., Sandu I.G., Paun E. \& Sandu I. Chemism of Streams Within the Siret and Prut Drainage Basins: Water Resources and Management. Rev. Chim. (Bucharest), vol. 64, no. 12, pp. 1416-1421, 2013.

[16] Romanescu G., Zaharia C., Paun E., Machidon O. \& Paraschiv V. Depletion of watercourses in north-eastern Romania. Case study: the Miletin river. Carpathian Journal of Earth and Environmental Sciences, vol. 9, no. 1, pp. 209-220, 2014.

[17] Romanescu G., Cojoc G.M., Sandu I.G.,Tirnovan A., Dascalita D. \& Sandu I. Pollution Sources and Water Quality in the Bistrita Catchment (Eastern Carpathians). Rev. Chim. (Bucharest), vol. 66, no. 6, pp. 855-863, 2015.

[18] Chen Z.M., Yeh Y.L. \& Chen T.C. Assessment of a Regional Flood Disaster Indicator via an Entropy Weighting Method. Natural Hazards Review, vol. 19, no. 2. 2018. https://doi.org/10.1061/(ASCE)NH.1527-6996.0000280

[19] Radevski I., Gorin S., Dimitrovska O., Milevski I., Apostolovska-Toshevska B., Talevska M. \& Zlatanoski V. Estimation of maximum annual discharges by frequency analysis with four probability distributions in case of nonhomogeneous time series (Kazani karst spring in Republic of Macedonia). Acta Carsologica, vol. 45, no. 3, pp. 253-262, 2016. 
[20] Radevski I. \& Gorin S. Floodplain analysis for different return periods of river Vardar in Tikvesh valley (Republic of Macedonia). Carpathian Journal of Earth and Environmental Sciences, vol. 12, no. 1, pp. 179-187, 2017.

[21] Reti K.O., Malos C.V. \& Manciula I.D. Hydrological risk study in the Damuc village, the Neamt county. Journal of Environmental Protection and Ecology, vol. 15, no. 1, pp. 142-148, 2014.

[22] Romanescu G. \& Nistor I. The effect of the July 2005 catastrophic inundations in the Siret River's Lower Watershed, Natural Hazards, vol. 57, no. 2, pp. 345-368, 2011.

[23] Romanescu G., Zaharia C. \& Stoleriu C, Long-term changes in average annual liquid flow river Miletin (Moldavian Plain). Carpathian Journal of Earth and Environmental Sciences, vol. 7, no. 1, pp. 161-170, 2012.

[24] Romanescu G., Cotiuga V., Asandulesei A., Stoleriu C. Use of the 3-D scanner in mapping and monitoring the dynamic degradation of soils. Case study of the Cucuteni-Baiceni Gully on the Moldavian Plateau (Romania). Hydrology and Earth System Sciences, vol. 16, pp. 953-966, 2012.

[26] Romanescu G. \& Stoleriu C. Exceptional floods in the Prut basin, Romania, in the context of heavy rains in the summer of 2010. Natural Hazards and Earth System Sciences, vol. 17, pp. 381-396, 2017.

[25] Romanescu G., Tarnovan A., Sandu I.G., Cojoc G.M., Dascalita D. \& Sandu I. The Quality of Surface Waters in the Suha Hydrographic Basin (Oriental Carpathian Mountains). Rev. Chim. (Bucharest), vol. 65, no. 10, pp. 1168-1171, 2014.

[27] Romanescu G., Hapciuc O.E., Minea I. Iosub M. Flood vulnerability assessment in the mountain-plateau transition zone. Case study for Marginea village (Romania), Journal of Flood Risk Management, vol. 11, no. S1, pp. S502-S513, 2018. Doi: 10.1111/jfr3.12249

[28] Romanescu G., Mihu-Pintilie A., Stoleriu C.C., Carboni D., Paveluc L.E. \& Cimpianu C.I. A Comparative Analysis of Exceptional Flood Events in the Context of Heavy Rains in the Summer of 2010: Siret Basin (NE Romania) Case Study. Water, vol. 10, no. 2, pp. 1-17, 2018.

[29] Romanescu G. \& Stoleriu C. Causes and Effects of the Catastrophic Flooding on the Siret River (Romania) in July-August 2008, Natural Hazards, vol. 69, pp. 1351-1367, 2013.

[30] Romanescu G. \& Stoleriu C, An inter-basin backwater overflow (the Buhai Brook and the Ezer reservoir on the Jijia River, Romania). Hydrological Processes, vol. 28, no. 7, pp. 31183131, 2013.

[31] Romanescu G., Cimpianu C.I., Mihu-Pintilie A. \& Stoleriu C.C. Historic flood events in NE Romania (post-1990), Journal of Maps, vol. 13, no. 2, pp. 787-798, 2017.

[32] Nicu I.C. \& Romanescu G. Effect of natural risk factors upon the evolution of Chalcolithic human settlements in Northeastern Romania (Valea Oii watershed). From ancient times dynamics to nowadays degradation. Zeitschrift für Geomorphologie, vol. 60, no. 1, pp. 1-9, 2016.

[33] Romanescu G., Stoleriu C. \& Romanescu A.M. Water reservoirs and the risk of accidental flood occurrence. Case study: Stanca-Costesti reservoir and the historical floods of the Prut river in the period July-August 2008, Hydrological Processes, vol. 25, no. 13, pp. 2056-2070, 2011.

[34] Romanescu G. \& Stoleriu C. Anthropogenic interventions and hydrological-risk phenomena in the fluvial-maritime delta of the Danube (Romania). Ocean\&Coastal Management, vol. 102, pp. 123-130, 2014.

[35] Sandulescu M. Geotectonica Romaniei, Editura Tehnica, Romania. 1984.

[36] Romanescu G., Lupascu A., Stoleriu C., Raduianu D., Lesenciuc D. \& Vasiliniuc I. Inventarierea si tipologia zonelor umede si apelor adanci din Carpatii Orientali. Editura Terra Nostra, 2010. 
[37] Apostol L. Precipitatiile atmosferice in Subcarpatii Moldovei, Editura Universitatii Suceava, 2000. 